\title{
An exploratory survey of undergraduate nursing students' experiences of group work within a Problem-Based Curriculum
}

\author{
P Brysiewicz, MCur,School of Nursing, University of Natal \\ R Cassimjee, MCur, School of Nursing,University of Natal \\ P Mclnerney, PhD, School of Nursing, University of Natal
}

\section{Abstract}

Problem-based Learning is a learner-centered approach to education which encourages student participation and group work in the learning process. This method of selfdirected learning is facilitated by the use of small-group discussions. This being the case, it is important for groups to function effectively in order for this learning to occur. These small groups are guided by a facilitator and utilize real-life problems from the clinical settings.

An exploratory survey using open-ended questionnaires was conducted amongst senior nursing students at the University of Natal, and this focussed on their experiences of group work. The students described their best and worst experiences as a member of a group, as well as what they found most irritating and most appreciated about the group work. The students also highlighted what they expected from the group and in turn what they were willing to do for the group

\section{Abstrak}

Probleemgesentreede leer is 'n leerdergesentreerde benadering tot onderrig waar student deelname en groepwerk binne die leerproses aangemoedig word.

Hierdie selfgerigte leermetode word deur kleingroepbesprekings gefasiliteer. Dit is dus belangrik vir die groepe om effektief te funksioneer om sodoende te verseker dat die leer plaasvind. Hierdie kleingroepe word deur ' $n$ fasiliteerder begelei en benut werklike probleme vanuit die kliniese situasie.

'n Ondersoekende opname met 'n vraelys bestaande uit oopvrae wat op die ondervindinge van groepwerk gebaseer was, is met senior verpleegkundestudente aan die Universiteit van Natal uitgevoer. Die studente het hul beste en swakste ondervindinge as lid van 'n groep sowel as die aspekte wat hulle as die mees irriterende en mees gewaardeerde betreffende die groepwerk beskou het, beskryf. Die studente het ook daardie aspekte wat hulle van die groep verwag het en wat hulle bereid was om in ruil vir die groep te doen, beklemtoon.

\section{Introduction}

For students following a problem-based curriculum, group work is an essential component. Students may however experience difficulties in working in groups, as they are often not accustomed to this process. In many cases the transition from a secondary school education, which has largely been lectured based and dependent on individual performance, can be difficult.

Learners enter into educational programmes to take something away with them when they complete. They expect to pay for a programme of study and get information from an expert in that field. Imagine their surprise when they realize that they have to seek information for themselves and still share that with others in the group. What then are they paying for? This is a common reaction, which course instructors encounter when they present a cooperative learning programme. Learners are selfish about what they learn and how they learn it. The idea of sharing and teaching each other has to be inculcated into the learners early in the programmes. This being the case, the researchers thought it important to test students understanding and appreciation of group activi- ties.

\section{Literature Review}

The literature that was reviewed ranged from research done with students and faculty involved with group work, to the nursing team working toward quality patient care. The literature also drew information from non-nursing groups, for example engineering classes in tertiary education. Information was divided into three simple categories which served the research objective of this study. These were the concept of group work, peoples' experiences within groups and group skills.

\section{The concept "Group Work"}

Education and training in general is predominantly teachercentered. This means that the students are taught by an expert in their field of study. Thereby making the students passive recipients of this unquestioned knowledge. In the last two decades education has moved to a more student-centred 
and shared active learning initiative.

Problem-based learning, self-directed learning and cooperative learning are all terms used to encompass this move, that is, getting the learner to realize that they need to work together, by sharing information in the learning environment. The students are the most important entity and therefore they have an active role to play in how and what the learning turns out to be. Curricula around the world are realizing the strengths of this type of teaching/learning strategy and accepting this process of active learning through groups.

McDonald (1995:1-2) stated that students learn best when they interact with other group members and share their ideas. Since the instructor is no longer the focal point of the class, he/she becomes more involved in creating the group structure and ensuring that the groups are functioning as teams. The same researcher also found that cooperative learning was well received by students. Kaufman, Felder \& Fuller (2000:133) stated that "cooperative learning is an instructional paradigm in which teams of students work on structured tasks". The same authors cite five criteria for this learning to occur. These are:

- $\quad$ Positive interdependence
- $\quad$ Individual accountability
- $\quad$ Appropriate use of collaborative skills
- $\quad$ Regular self-assessment of team functioning

According to Smith, (1995:5), the facilitator has five main tasks. These are to:

Specify the objective for the lesson

- Make a number of instructional decisions

- $\quad$ Explain the task and the positive interdependence

- Monitor students' learning and intervene within the groups to provide task assistance or to increase stu -dents team work skills

- $\quad$ Evaluate students learning and help students process how well their group functioned

The instructor/facilitator has a managerial role in guiding the progress of the discussion. This shows that the responsibility for the content and pace of the learning is a group one. Appropriate and efficient functioning of a group will determine how much is learnt at a particular time. This requires a great commitment from members toward the group's progress. Smith (1995:4) goes on to say that for a group to be effective, members need to:

\section{- Have a clear positive interdependence}

- $\quad$ Promote each other's learning and success face-to-face

- Hold each other personally accountable to do his/her fair share of work

- $\quad$ Appropriately use the interpersonal and small-group skills learnt

- $\quad$ Process as a group how effectively members are working together

This shows that group work is a collaboration of different members' initiatives, skills and knowledge for effective learning.

\section{Experiences of people working in groups}

Sherman (1990:44) discusses the benefits of nurses working in teams. This author found that "team nursing is not possible without strong leadership and clear communication. The expected leadership style in this group is that of participatory". Sherman (1990:44) goes on to say that mechanisms such as team conferences allow for team-building and resolution of interpersonal conflicts, and these are essential for cohesive team functioning. In addition, McDonald (1995:5) writes that students have reported that working together and discussing the material helped their understanding of the subject. This helped them learn to discuss group problems, share responsibility and be more conscientious about completing work on time as the other members were relying on their input.

Long (1996:937) investigated team members' views of a multidisciplinary team workshop. This author found that team members were very conscious of the roles they personally played within a team but felt that their extended roles, (activities done outside the group) were not understood. It was also found that communication worked well only on an informal basis. This study found that there was poor communication between different disciplines and within similar disciplines. Conflict was concentrated on issues of communication and interpersonal issues.

\section{Group skills}

Antai-Otang (1997:49) found that for teams to be successful they need to have four essential qualities. These are:

$\begin{array}{ll}\text { - } & \text { Effective communication } \\ \text { - } & \text { Member involvement } \\ \text { - } & \text { Trust. }\end{array}$

Antai-Otang (1997:49) goes on to explain that this means that "active listening that is, using all senses to assess verbal as well as nonverbal messages toward a movement of conflict resolution" are crucial for effective communication within groups. A sense of commitment to the team, respect for each other and a desire to understand team dynamics are all positive evidence toward group involvement.

Biley \& Smith (1999:1208) investigated undergraduate students' perceptions of problem-based learning. When asked about their group processes, students mentioned that group functioning depends on the input of each student and the division of labour. Group collaboration was an essential skill for success. Sherman (1990:46) stated that cooperation was essential for team effectiveness, and elaborated that a theoretical framework for organizational development of teams was:

- - Team communication

Felder \& Brent (1996:5) found that students working on group assignments complained that some students did not pull their weight and relied on other students to start the discussions. The same students do not participate in the discussions. One 
recommendation that these authors suggest is that students learn to create a list of standards and expectations for themselves. The authors also suggest that group members sign the list and make a copy for all members. This would aid teams to stay in focus of their collaborative tasks. They also suggest that students work alone independently and complete tasks as homework before meeting for discussion. This would ensure that students all participate in the discussion by coming prepared.

McDonald (1995:5) found that group assignments in cooperative learning improved student learning, developed essential teamwork, communication and leadership skills. Students mentioned that the interaction of their views and the need to listen as well as express ideas gave them the opportunity to see other ideas.

Dana \& Gwele (1998:63) in a study on students' perceptions of their personal and academic development during community placement mentioned that students saw their peers as a source of support during their learning. Windsor (1987) cited in Dana \& Gwele (1998:63) stated that students provide emotional support to each other in clinical settings and this in turn reduces the likelihood of anxiety related to learning.

The cited literature clearly illustrates that there are positive implications for group learning. The literature briefly cited the meaning of "group work", researched experiences of people working within groups and the noted skills that groups need in order to function together effectively. With these in mind the researchers aim to investigate students' personal experiences with group work.

\section{Problem Statement}

Students working in a problem-based curriculum find difficulty in working in groups since they are not accustomed to the process. Secondary school education in South Africa has, by and large been lecture-based and dependent on individual performance. Students find this transition difficult and often have their grades suffer due to the inability of understanding the functioning of a group discussion. This study aims to visit the perceptions of students regarding their own experiences of group work.

\section{Purpose of the study}

The purpose of this study was to use an exploratory survey to establish the perceptions of the nursing students' experiences of group work at the University of Natal.

\section{Research question}

How do nursing students experience working in groups?

\section{Objectives of the study}

The objectives of this study were to:

- Describe the student's positive and negative experiences as a member of a group.

- Identify factors that influence an individual's experiences as a member of a group.

\section{Definition of terms}

\section{Group work}

Students working in groups of 10 to 15 , for the purpose of sharing and discussing information and experiences related to an identified area of learning.

\section{Students}

For the purpose of this study this was taken to mean the senior nursing students registered at the University of Natal, and currently in their third or fourth year of study.

\section{Ethical considerations}

The students were given a verbal explanation of the objectives of the research and a request for verbal consent was made before the researchers distributed the questionnaires. The questionnaire also contained a covering letter explaining the purpose of the research and the researchers' contact details. The students were informed of their right to withdraw from the research at any time and were assured that all their responses would be confidential, as the questionnaires were anonymous.

\section{The research design}

An exploratory survey was conducted amongst the senior nursing students using a semi-structured questionnaire. This questionnaire focussed on the students' experiences of group work the most irritating aspects of group work, what the students expected from their groups and what the students were willing to do for their own group. An evaluation form given to students in previous years provided a framework for the development of the questionnaire.

\section{The setting}

The nursing students in the baccalaureate Problem-Based Learning programme at the University of Natal: Durban (UND) spend their first two years in Fundamental Nursing and Community Health Nursing respectively. Their third year is spent in Medical-Surgical Nursing, and in their final year they are exposed to Midwifery and Mental Health Nursing. Throughout their training, these students are expected to work in groups and they are thus well exposed to group work. For the above mentioned programme to be successful it is thus essential that their group work be made as beneficial as possible and it is for this reason that the researchers have elected to concentrate on this area.

\section{The population and sample}

The population comprised of all the students in the undergraduate programme. In 1998 there was a total of 121 students enrolled in the four year nursing degree at the University of Natal. This was broken down as follows; 31 students in the first year, 31 students in second year, 32 students in third year and fourth year had 27 students.

The third and fourth year students constituted the sample ( $n$ =71). The students were purposively chosen because they had experienced a minimum of two years of group work, which was considered to be an adequate period of time for them to 


\section{The pilot study}

The first questionnaire was administered to a group of 19 third year students in January of 1998 - this served as a pilot study. This resulted in the questionnaire being refined as the respondents displayed a problem in understanding parts of the tool. The researchers also added two open-ended qualitative questions to complete the data being collected.

\section{Data collection}

This revised tool was then re-administered to the same respondents ten months later. This comprised the first group of participants.

The questionnaire was then administered to another group of $3^{\text {rd }}$ year students in January 1999 (at the beginning of their $3^{\text {rd }}$ year) and then re-administered to this same group of students in October 2000 (at the end of their fourth year). This made up the second group of students.

This survey was carried out over a period of 2 years and 10 months (from January 1998 to October 2000) and all the ques- periences of working in a group. A self-administered questionnaire was chosen as the means of data collection in order to facilitate accuracy of responses. Time was given during the problem-based tutorial session for students to complete the questionnaire.

\section{Data analysis}

Data were analysed manually. Use was made of frequencies and percentages to present the findings.

\section{Findings of the study}

Worst and best experiences as a member of a group The students were asked to describe the best and worst experiences they had had as a member of their group the previous year.

\section{Factors related to work}

Poor levels of co-operation within the group, lack of enthusiasm and group members not talking in the group discussions were noted as bad group experiences for some students.

\section{Table 1: Irritating aspects of group work $(n \neq 71)$}

\begin{tabular}{|l|c|c|}
\hline & Frequency & Percentage \\
\hline Absenteeism & 6 & 8.4 \\
\hline Late & 7 & 9.8 \\
\hline Domination & 11 & 15.4 \\
\hline Talking at the same time & 4 & 5.6 \\
\hline Laughing & 8 & 11.2 \\
\hline Quiet members & 5 & 7 \\
\hline Unprepared for group & 14 & 19.7 \\
\hline Not participating & 10 & 14 \\
\hline Uncooperative group & 4 & 5.6 \\
\hline Not listening & 4 & 5.6 \\
\hline Inappropriate information & 5 & 7 \\
\hline Disruptive behaviour & 11 & 15.4 \\
\hline Lazy students & 3 & 4.2 \\
\hline Problems with the facilitator & 3 & 4.2 \\
\hline
\end{tabular}

tionnaires during this period were analyzed.

\section{Reliability and validity}

The questionnaire was subjected to a pilot study and it was then decided to add two open-ended questions. These questions asked students to describe their best and their worst ex-
The responses from the questionnaires showed that the students valued working well as a group to achieve the tasks. One of the students said; "working as a group is like collecting different pieces to make one good object. We put all our knowledge together and came up with something good". A number of the students described how their best experiences within a group revolved around the sharing of experiences, 
be they work or personal experiences, as this then added to their own knowledge.

The students also highlighted the importance of active participation by all in order to make the most of the group work. A student noted that; "being in a small group was very nice, especially because everyone has a chance to get an opportunity to contribute and also if you are not sure someone will always explain it to you".

Some of the students marked on the questionnaire that their best experiences as a member of a group was that it increased their confidence and maturity. It also enabled students to learn the importance of taking responsibility and cultivated skills such as being able to facilitate a group on their own!

\section{People factors}

The students stressed how unsettling it was for the group to rience was "being looked down upon, that I don't know as much as the other members do".

The importance of being comfortable with each other, of respecting and getting to know each other very well, even the facilitator, were also factors which were considered to contribute to the experiences of group work. One of the students suggested that their best experience as a member of a group was; "getting to know the members (of the group) in more detail, their cultural background and experiences and relating or understanding it in my life contents".

The students also mentioned encouraging and supporting each other, and listening attentively to what each other was saying. Partnership and relationship building were also noted as some of the best experiences within the group. One of the students summed it up by saying; "watching the students grow closer together. Being able to communicate about anything. It is remarkable to know that the group members are

\section{Table 2: Things most appreciated $(\mathbf{n \neq 7 1 )}$}

\begin{tabular}{|l|c|c|}
\hline & Frequency & Percentage \\
\hline Helptul facilitator & 9 & 12.6 \\
\hline $\begin{array}{l}\text { Participation by group } \\
\text { members }\end{array}$ & 17 & 23.9 \\
\hline $\begin{array}{l}\text { Cooperation by group } \\
\text { members }\end{array}$ & 3 & 4.2 \\
\hline Teamwork & & 32.3 \\
\hline Well prepared & 23 & 15.4 \\
\hline Hard working & 11 & 4.2 \\
\hline Good attendance & 3 & 2.8 \\
\hline Issues related to time & 2 & 2.8 \\
\hline Respect & 2 & 9.8 \\
\hline Improved learning & 7 & 2.8 \\
\hline Opportunity to clarify issues & 2 & 7 \\
\hline Being resourceful & 5 & 1.4 \\
\hline
\end{tabular}

have members who arrived late for class or were unprepared or appeared disinterested in the group by not doing their work. Irresponsible and lazy group members were a problem as they then relied on others to get the tasks done. This created further problems as one student said that the worst experience of the group was "knowing that marks are not allocated on individuals but on a whole group".

The lack of cohesion in the group (for example, taking a long time to resolve a problem or the problem not being solved in the end) was a bad experience for a number of students.

One of the students also noted that for them their worst expe- close and overface (overcome) whatever obstacles that stand in our way".

\section{Most irritating aspects of group work}

When listing the aspects that irritated them as a member of a group, the students had a number of common responses and these are shown in Table 1.

Domination was identified by $15.4 \%(n=11)$ of the students as being an irritating aspect of group work, with laughing at members of the group scoring $11.2 \%(n=8)$. Being unprepared for the group session and not doing the work for the 
group scored as the most irritating aspect amongst the participants ( $n=14 / 19.7 \%$ ). Not participating in the group discussions $(n=10 / 14 \%)$ and disruptive behaviour by the group members $(n=11 / 15.4 \%)$ was also highlighted. Some of the participants cited problems with the facilitator as being their most irritating aspect of group work $(n=3 / 4.2 \%)$. This included the facilitator not being specific about the objectives and structure of the class, rephrasing information incorrectly and sidetracking the group.

\section{Things most appreciated about the group}

The students expressed a number of aspects which they appreciated the most in a group and these are shown in Table 2. A helpful facilitator was viewed by $12.6 \%(n=9)$ of the stu- and understanding weaker students and all having equal tasks to do. Being well prepared was also expressed by a number of the students $(n=11 / 15.4 \%)$ although a surprisingly few appreciated their group members being resourceful $(n=1 /$ $1.4 \%)$

\section{What is expected from the group}

The students were asked to highlight what they expected the group to do for them and these findings are illustrated in Table 3 .

A large majority of the students expected the group to work together, to help when there were problems and function well together $(n=40 / 56.3 \%)$. Respecting group members $(n=11$ $/ 15.4 \%)$ and participation in the group $(n=18 / 25.3 \%)$ were also seen as expectations of the group. Communication was seen by $15.4 \%(n=11)$ of the students as an expectation

\section{Table 3: Expected from the group $(n \neq 71)$}

\begin{tabular}{|l|c|c|}
\hline & Frequency & Percentage \\
\hline Working together & 40 & 56.3 \\
\hline Respect group members & 11 & 15.4 \\
\hline Participation & 18 & 25.3 \\
\hline Meeting group goals and aims & 7 & 9.8 \\
\hline Cooperating & 6 & 8.4 \\
\hline Sharing information & 3 & 4.2 \\
\hline Communication & 11 & 15.4 \\
\hline Punctuality & 5 & 7 \\
\hline Prepare well & 9 & 12.6 \\
\hline Personal characteristics & 8 & 12.2 \\
\hline group members & & 15.4 \\
\hline Responsible & 11 & 7 \\
\hline Enthusiastic group & 5 & 1.4 \\
\hline Obey group rules & 1 & 1.4 \\
\hline Attendance & 1 & 2.8 \\
\hline Make sacrifices for the group & 2 & \\
\hline
\end{tabular}

dents as being what they appreciated most in a group. This was seen by the students as being helpful when you have a problem, understanding and guiding the group and motivating the students. Participation by group members was also appreciated by a number of students $(n=17 / 23.9 \%)$. The students also mentioned that teamwork was appreciated $(n=$ $23 / 32.3 \%$ ), and this included sharing ideas, knowledge and experiences, learning from each other, encouraging each other and this included discussing as a group if something was wrong and understanding each other. Being responsible was also expressed by $15.4 \%(n=11)$ of the students as being expected from the group.

\section{Willing to do for the group next year}

The students were asked what they were willing to do for 
their group in the following year and their responses are shown in Table 4.

Only $18.3 \%(n=13)$ of the students said that they were willing to access and share information and $29.5 \%(n=21)$ said they would do the work allocated to them. The aspect which most were willing to do $(n=28 / 39.4 \%)$ was to participate actively in the group. Various personal characteristics were cited by $19.7 \%(n=14)$ of the students as what they would be willing to do for their group. These included being motivated, working hard, volunteering to do the work, being responsible, approachable and being willing to make sacrifices for the group.

\section{Discussion of the findings Domination}

Whilst only $15.4 \%(n=11)$ of the students mentioned domination by some group members as the most irritating aspect of group work, it is interesting to note that this concept was not an issue in Biley and Smith's study (1999:1208). In their study students acknowledged that there were those who were ting students to work in teams. Students even protested to the department head of their dislike of team work. A staff member was quoted in Felder and Brent (1996:5) to state that if he/she assigns homework, presentations or projects, some students would "hitchhike", and not participate, thus getting credit for work in which they did not participate. These authors go on to advise that individual tests and tasks would assist in alleviating this problem and also that students who do this routinely would generally fail tests.

Active participation ( $n=28 / 39.4 \%)$ and doing work allocated ( $n=21 / 29,5 \%)$ were the two most commonly named activities that students were willing to do for the group. Only $18,3 \%(n=13)$ stated that they were willing to access and share information with the group. This is consistent with Biley and Smith's finding (1999:1208) that some students withheld their best information in order to have the edge over other students.

\section{Facilitators}

It was disturbing to note that a few students identified facilitator behaviour as irritating. However, this finding is consist-

\section{Table 4: Things willing to do for the group $(n \neq 71)$}

\begin{tabular}{|l|c|c|}
\hline & Frequency & Percentage \\
\hline Access and share information & 13 & 18.3 \\
\hline Do work allocated & 21 & 29.5 \\
\hline Punctual & 7 & 9.8 \\
\hline Attend group & 6 & 8.4 \\
\hline Participate actively & 28 & 39.4 \\
\hline Cooperation & 5 & 7 \\
\hline Prepare for group & 4 & 5.6 \\
\hline Put the group on track & 1 & 1.4 \\
\hline Personal characteristics & 14 & 19.7 \\
\hline Respect & 7 & 9.8 \\
\hline Help and encourage others & 8 & 12.2 \\
\hline Follow group rules & 3 & 4.2 \\
\hline Listen to others & 4 & 5.6 \\
\hline
\end{tabular}

passive and those who were more extrovert. It was noted that when the extrovert members were absent, the session was "fragmented and disinterested".

\section{Participation}

One of the students commented about group work saying that; "it became fun-filled the more I participated."

Felder and Brent (1996:5) stated that staff have difficulty get- ent with that of Biley and Smith (1999:1208) who found that confusion arose in the group when the facilitator displayed what was perceived as "inconsistent behaviour". Moust has proposed a theory of tutor performance and how it relates to student performance. Cognitive congruence is a key concept in his theory. It includes the ability of the facilitator to be able to adapt to the student's level of understanding of the subject matter, sensitivity to the problems that students may have in dealing with the subject matter related to the problem. This 
requires that the facilitator know when to intervene and what to offer - either in the way of clarification or a brief explanation. Moust states that a facilitator is only able to do this if he I she has knowledge of the relevant subject matter. In addition to subject matter knowledge the facilitator must have a genuine and personal interest in the students and their learning (Schmidt and Moust 1995:709).

Wilkerson, (1995:309-311) in a study that identified the skills of the problem-based tutor reported that students found tutors helpful, when they allowed students to control the focus of the discussion. Students also rated tutors helpful when they encouraged critical thinking. The same author quoted students to state that facilitators were helpful when they created a pleasant and conducive environment to learning.

Feletti, Doyle, Petrovic, \& Sansan-Fisher (1982:196) found that tutors are seen to fulfil a leadership role, where their main task is to develop and facilitate the cohesion of the group, while caring for individuals.

A student suggested that "the group needs a co-operative facilitator and a strict one!"

\section{Teamwork}

"Group work is very important and useful especially for us nurses since we are going to spend most of our time working with different people, therefore it helps us in acquiring certain skills needed in order to be able to work with different types of people" (nursing student).

Muller (1996:210) stated that effective nursing care needed nurses to work in teams. The team needed participative leadership. This means that all members play an active role in task performance and goal achievement. McDonald (1995:3) stated that teamwork skills are promoted as the group learns to make decisions, assign tasks and resolve conflict.

The findings of this study indicate that students were learning skills in addition to the knowledge component of the programme. Amongst these skills were the importance of teamwork and group participation, communication skills and respect for differing opinions. It was disappointing to find that only one student stated that she/he appreciated someone who is resourceful. It appears that students are not aware of or had not learnt to value their own or others' contributions to the group. Interestingly this finding is consistent with that of Biley and Smith (1999:1210).

Muller (1996:215) stated that teams need creativity and flexibility amongst its members. Experimentation with new ideas should be encouraged within the group to address problems in the best way possible.

\section{Communication}

In this study laughter was identified by students as an instance which created their worst experiences in group work. Laughing whilst others are speaking and being laughed at are belittling and intimidating experiences. Barnes writes that valuing students' contributions is the first requirement for successful group work and furthermore, it may form the basis for genuine communication (Prawat, 1989:323).

Biley \& Smith (1999:1208) quoted students to state that a "percentage of the group let us down by not turning up or not pulling their weight". These authors state that participants in their study understood that the PBL process depends on group collaboration for its success. McDonald (1995:1) stated further that group assignments forced students to be accountable to each other and thus promote communication and team work skills that would help students.

The importance of good communication skills was alluded to by a number of the students. Only $15.4 \%(n=11)$ of the students mentioned that they expected the group to communicate well and the students valued getting to know each other, sharing experiences and ideas - all of this is not possible without good communication skills. One of the student's described how their communication skills developed saying; "my worst learning experience was trying to reiterate that everything (was) to (be) done properly and sometimes making people angry because of this, however as I developed within the group I was able to put my point across without angering anyone".

\section{Limitations of the study}

The researchers were the facilitators of some of these groups and this possibly coloured the student's responses as they might have felt inclined to give the responses they knew their facilitators would like. A further limitation to the study was the fact that the first group of students completed the questionnaire twice in one year, albeit that the second was a revised questionnaire. Another limitation of this study is that the findings of the study cannot be generalised due to the size of the sample.

\section{Recommendations}

The researchers identified the need for further in-depth research on how the students perceive working in a group. There is also a need to conduct a similar study with a larger sample size that would facilitate comparison of findings between groups.

The importance of establishing group norms and rules within the group at the beginning of each year has been highlighted by the findings of the research and is recommended in practice.

\section{Conclusion}

From the results the researchers are of the opinion that the students appear to have grasped the importance of group work and co operative learning. They appear to be aware of what is needed to get the most out of their groups and how the groups can in turn help them. In concluding the students summed up the experience of group work by saying; "I understand it and enjoy it. I hope that I can manage a group of my own now" and "It definitely works!"

\section{References}

ANTAI-OTONG, D 1997: Team building in a health care setting. Advanced Journal of Nursing. 97 (7) : 49-51.

BILEY, FC \& SMITH, KL 1999: Making sense of problem-based learning: the perceptions and experiences of un- 
DANA, N \& GWELE, NS 1998: Perceptions of student nurses of their personal and academic development during placement in the community as a clinical learning environment. Curationis. 21 (1): 58-64.

FELDER, RM \& BRENT, R 1996: Navigating the bumpy road to student-centered instruction. College Teaching. 44: 43-47.

FELETTI, GI, DOYLE, E, PETROVIC, A \& SANSANFISHER, R 1982: Medical students' evaluation of tutors in a group-learning curriculum. Medical Education. $16: 319$ 325.

KAUFMAN, DB , FELDER, RM \& FULLER, H 2000: Accounting for individual effort in cooperative learning teams. Journal of Engineering Education. 89 (2) : 133-140.

LONG, S 1996: Primary health care team workshop: team members' perspectives. Journal of Advanced Nursing. 23 : 935-941.

MCDONALD, D 1995: Improving student learning with group assignments.

www.ecn.purdue.edu/fre/asee/fie95/2b5/2b53/2b53.htm

MULLER, M 1996: Nursing Dvnamics. Second Edition. Heinemann Higher and further education. Sandton: Johannesburg.

PRAWAT, RS 1989: Teaching for understanding: Three Key Attributes. Teaching and Teacher Education. 5 (4) : 315-328.

SCHMIDT, HG \& MOUST, JHC 1995: What makes a tutor effective? A structural-equations modeling approach to learning in problem-based curricula. Academic Medicine. 70 (8) : 708-714.

SHERMAN, RO 1990: Team nursing revisited. Journal of Nursing Administration. 20 (11) : 43-46.

SMITH, KA 1995: Cooperative learning: Effective teamwork for engineering classrooms. www.ecn.purdue.edu/fre/ asee/fie $95 / 2$ b5/2b53/2b53.htm

WILKERSON, L 1995: Identification of skills for the problem-based tutor: Student and faculty perspectives. Instructional Science. 22 :303-315. 